\title{
Wartości dawek w tkankach zdrowych w zależności od anatomii i kształtu piersi w grupie pacjentek z nowotworem piersi
}

\section{Dose values in healthy tissues depending on the anatomy and shape of the breast in the group of patients with breast cancer}

\author{
Sara Styś ${ }^{1}$, Magdalena Charmacińska ${ }^{1}$, Agnieszka Skrobała ${ }^{2,1}$ \\ ${ }^{1}$ Zakład Fizyki Medycznej, Wielkopolskie Centrum Onkologii, Poznań \\ ${ }^{2}$ Katedra i Zakład Elektroradiologii, Uniwersytet Medyczny Poznań; Zakład Fizyki Medycznej
}

\section{Streszczenie}

Ponad 20\% zachorowań na nowotwory u kobiet w Polsce, jak i na świecie stanowią nowotwory piersi. Celem pracy była analiza wpływu anatomii i kształtu piersi w grupie pacjentek z nowotworem piersi lewej poddanych radioterapii na dawki promieniowania jonizującego dostarczane do tkanek zdrowych. Po analizie otrzymanych danych, podjęto próbę wypracowania wytycznych dla pacjentek ze szczególnie niekorzystną anatomią w kontekście radioterapii. Analizą zostało objętych 50 pacjentek leczonych z powodu nowotworu lewej piersi metodą trójwymiarowej radioterapii konformalnej. Do oceny wpływu anatomii pacjentek na dawki dostarczane do tkanek zdrowych (płuc i serca) wykorzystano analizę histogramów dawka-objętość. Stwierdzono, że na dawki w analizowanych narządach, sercu i płucach największy wpływ ma kształt piersi oraz wielkość klinicznej objętości napromienianej. U pacjentek posiadających duże piersi opadające, gdy nie ma możliwości zastosowania techniki napromieniania na głębokim wstrzymanym wdechu ze względu na ograniczenia wynikające ze stanu zdrowia pacjentki lub możliwości techniczne ośrodka, korzystne jest stosowanie innych niż standardowe unieruchomienia np. pozycja na brzuchu.

\footnotetext{
Abstract

Adres do korespondencji

Agnieszka Skrobała

Pracownia Planowania Teleradioterapii, Zakład Fizyki Medycznej,

Wielkopolskie Centrum Onkologii, ul. Garbary 15, 61-866 Poznań, Polska

Telefon. +48618850553

e-mail: agnieszka.skrobala@wco.pl
}

Over 20\% of cancer incidence in the group of women in Poland and the world is breast cancer. The aim of the study was to analyze the influence of anatomy and breast shape in the group of patients with left side breast cancer undergoing radiotherapy delivered to healthy tissues. After analyzing the obtained data, an attempt was made to develop guidelines for patients with particularly unfavorable anatomy in the context of radiotherapy. The analysis covered 50 patients who were treated by three-dimensional conformal 
radiotherapy. Analysis of dose-volume histogram was used to assess the impact of patients' anatomy on doses to healthy tissues: lungs and heart. It was found that the dose in the lungs and the heart of the most affected breast shape and size. There was no influence of the shape and size of the chest. For patients with large, drooping breasts, when it is not possible to use deep inspiratory breath hold technique due to the limitations resulting from the patient's health or the center's technical capabilities, it is preferable to use nonstandard immobilization, for example, prone position.

Słowa kluczowe: radioterapia, nowotwór piersi, narzady krytyczne, trójwymiarowa radioterapia konformalna

Keywords: radiotherapy, breast cancer, organ at risks, three-dimension conformal radiation therapy

\section{Wstęp}

Ponad 20\% zachorowań na nowotwory kobiet w Polsce, jak i na świecie stanowią nowotwory piersi $[1,2]$. Od lat są one jedną z głównych przyczyn zgonów wśród pacjentek onkologicznych [2]. Istotnym elementem leczenia nowotworów piersi jest radioterapia, jest to metoda wykorzystująca promieniowania jonizujące w terapii.

Radioterapia jest integralną częścią leczenia nowotworów piersi we wczesnym stadium i zwykle jest stosowana na obszar piersi po zabiegu oszczędzającym BCS (ang. Brest conserving surgery) [4]. Wyniki uzyskane $\mathrm{w}$ badaniach $\mathrm{z}$ randomizacją przeprowadzone przez Elary Breast Cancer Trialists Collaborative Group (EBCTCG) [5] ujawniły, że radioterapia całej piersi WBI (ang. Whole breast irradiation) po BCS zmniejsza o połowę wskaźnik nawrotów choroby, a śmiertelność zmniejsza się sześciokrotnie w przypadku wczesnego stadium zaawansowania raka piersi. Konwencjonalne podejście do WBI polega na zastosowaniu trójwymiarowej radioterapii konformalnej 3DCRT (ang. three dimension conformal radiationtherapy), wykorzystującej dwa pola tangencjalne [5]. Układ wiązek jest tak dobierany, aby obejmował całą pierś (z uwzględnieniem ruchomości oddechowej). Jednak podejście to wiąże się z pewnymi wyzwaniami polegającym na uzyskaniu jednorodnego rozkładu dawki w objętości piersi leczonej [6] z jednoczesnym dostarczeniem dawki na skórę i w sąsiednich narządach, narządach krytycznych, co może skutkować podwyższoną toksycznością leczenia [7]. Narządy krytyczne OARs (ang. organs at risk) to narządy znajdujące się w pobliżu objętości napromienianej, w przypadku radioterapii piersi są to między innymi płuca i serce. Narządy krytyczne posiadają ściśle zdefiniowane dawki tolerancji, których przekroczenie grozi powikłaniami popromiennymi. Dawki tolerancji dla poszczególnych narządów zebrano w raportach, jednym z takich raportów jest raport QUANTEC [8]. Stąd jednym z zadań prawidłowej realizacji radioterapii jest oszczędzenie tkanki płucnej w obszarze napromienianym. W przypadku radioterapii piersi najprostszym sposobem oszczędzenia tkanki płucnej jest zachowanie odległości od wewnętrznej powierzchni klatki piersiowej do zewnętrznej powierzchni płuca nie przekraczającej $3 \mathrm{~cm}$ (co stanowi 10-15\% objętości napromienianego płuca). Dodatkowo stosowane są techniki mające na celu ograniczenie dawek w tkankach zdrowych, tzw. narządach krytycznych. Doskonałym przykładem takiej techniki jest napromienianie na głębokim wstrzymanym wdechu DIBH (ang. deep inspiratory breath hold). Niestety wspomniane nowoczesne techniki nie są jeszcze wdrożone we wszystkich ośrodkach radioterapii, ze względu na koszty. Zdarza się również, że pomimo dostępności zaawansowanych technik leczenia nie ma możliwości zastosowania ich u wszystkich pacjentek. Ponad to część chorób współistniejących takich, jak astma czy obturacyjna choroba płuc, a także utrudniona możliwość nawiązania współpracy z pacjentką wynikająca z wieku chorej wyklucza zastosowanie techniki DIBH. Stąd przedstawione w pracy badanie przeprowadzono między innymi z myślą o tej szczególnej grupie pacjentek.

Celem pracy była ocena wpływu anatomii i kształtu piersi w grupie pacjentek z nowotworem piersi lewej poddanych teleradioterapii, na dawki promieniowania jonizującego dostarczane do tkanek zdrowych. Określono wpływ objętości napromienianej piersi, kształtu piersi oraz budowy anatomicznej klatki piersiowej, gdy pacjentka przyjmuje pozycję terapeutyczną, na dawki otrzymywane przez narządy krytyczne. W trakcie oceny dawek kierowano się wytycznymi raportu QUANTEC (30\% objętości płuc nie powinno otrzymać dawki przekraczającej 20 Gy, 10\% objętości serca nie powinno otrzymać dawki przekraczającej 25 Gy) [8]. 


\section{Materiał i metoda}

Analizą objęto 50 pacjentek poddanych leczeniu, z powodu nowotworu piersi lewej, metodą trójwymiarowej radioterapii konformalnej - 3DCRT [3]. Wybrano chore z nowotworem piersi lewej, ze względu na potencjalną bliskość serca od piersi, objętości napromienianej. Pacjentki poddane były radioterapii po operacji oszczędzającej (BCS). Dawką terapeutyczną objęto tylko objętość gruczołu piersiowego, kliniczną objętość napromienioną CTV (ang. clinical target volume) bez dołu pachowego zawierającego węzły chłonne.

Przed rozpoczęciem leczenia pacjentkom wykonano tomografię komputerową (TK), tomografem komputerowym Siemens Somatom Definition AS (Siemens AG, Germany), odległość między warstwami wynosiła $5 \mathrm{~mm}$. Każda z pacjentek miała wykonane przekroje TK w ułożeniu na wznak z rękoma uniesionymi za głową. Chore leżały na unieruchomieniu dedykowanym do pozycjonowania klatki piersiowej (CIVCO Medical Solutions, USA). Parametry ułożenia były dobierane indywidualnie dla każdej pacjentki, tak aby zapewnić optymalne ułożenie ciała chorej. Klatkę piersiową unoszono tak, aby jej przednia powierzchnia była równoległa do płaszczyzny stołu terapeutycznego. Na podstawie TK wykonywano plany leczenia w Systemie Planowania Leczenia (SPL) Eclipse ver. 15.6 (Varian Medical System, PaloAlto, USA).

Szczególnie narażone na promieniowanie jonizujące w trakcie radioterapii gruczołu piersiowego jest serce - ze względu na ryzyko wystąpienia zapalenia osierdzia lub zapalenia mięśnia sercowego [8]. Należy zwrócić uwagę także na płuca, bowiem dawka 27 Gy podana na obszar całego płuca jest obciążona 50\% prawdopodobieństwem wystąpienia przewlekłego zapalenia. Wyżej wymienione organy były narządami krytycznymi, które okonturowano w SPL. Ponadto została wyznaczona kliniczna objętość napromieniania CTV (ang. clinical target volume), obejmująca całą objętość piersi. Do obszaru CTV dodawano margines $5 \mathrm{~mm}$ tworząc planowaną objętość napromienioną PTV (ang. planing target volume), na którą zadawano dawkę [9,10]. Dawka frakcyjna wynosiła 2,25 Gy do dawki całkowitej 42,5 Gy. W planach stosowano technikę 3DCRT, w której tak dobierano geometrię dwóch głównych wiązek tangencjalnych, aby objąć swoimi wymiarami objętość PTV (rycina 1a,1b). Plan leczenia uzupełniano o dodatkowe pola z wykorzystaniem techniki „pole w polu” (ang. field in field). Zabieg ten stosowano celem podwyższenia lub obniżenia dawki w obszarze napromieniania, aby uzyskać optymalny, jednorodny rozkład dawki w objętości PTV.

a)

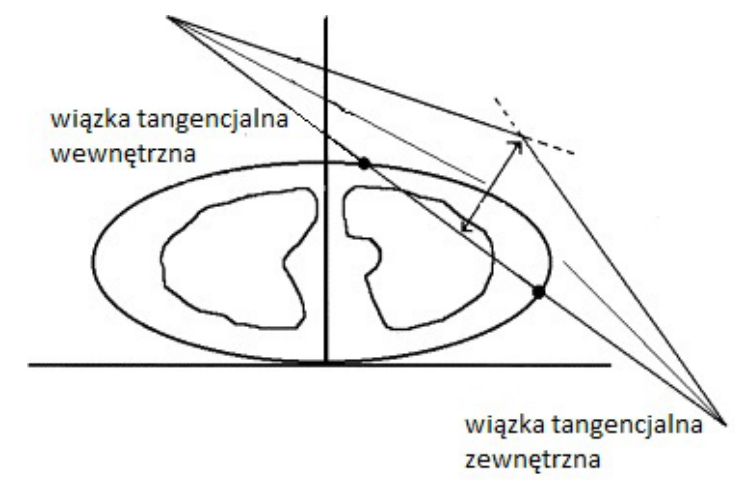

b)

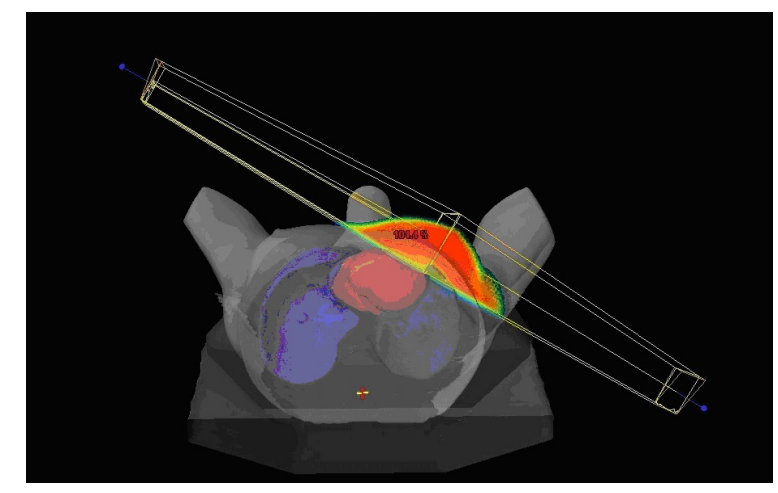

Rycina 1a). Schemat przedstawiający geometrię wiązek tangencjalnych dla pacjentek poddawanych radioterapii piersi. b). Wizualizacja geometria wiązek tangencjalnych, wraz z rozkładem dawki dla przykładowej pacjentki w systemie planowania leczenia.

Do oceny wpływu anatomii pacjentek na dawki w tkankach zdrowych tj. w płucach i sercu, wybrano parametry, które odczytywano między innymi z histogramów dawka-objętość. Pierwszy analizowany parametr stanowiła objętość klatki piersiowej, który został wyznaczony na przekrojach TK jako struktura obejmująca objętość ciała pacjentki od wysokości kręgu piersiowego TH1 do TH12. Objętość klatki piersiowej została zdefiniowana jako parametr V klatka $\left[\mathrm{cm}^{3}\right]$ (rycina 2). 


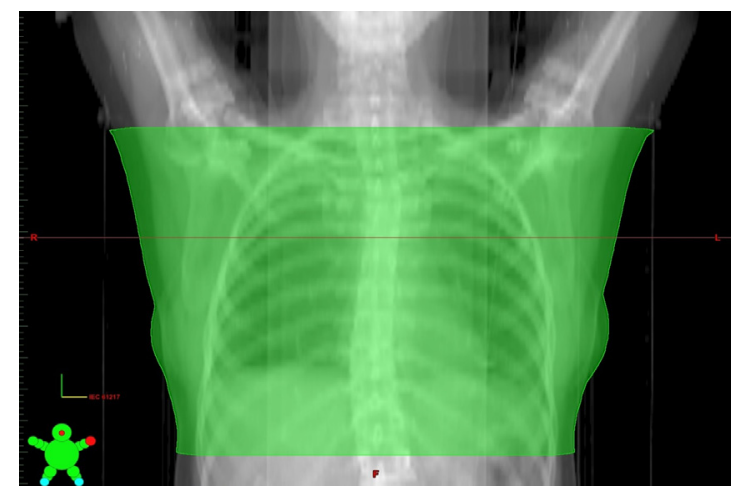

Rycina 2.Wizualizacja objętości klatki piersiowej zdefiniowana za pomocą parametru V klatka dla przykładowej pacjentki w systemie planowania leczenia.

Z planów leczenia odczytywano także: objętość CTV - VCTV $\left[\mathrm{cm}^{3}\right]$, objętość serca - Vserce $\left[\mathrm{cm}^{3}\right]$, objętość płuca lewego - VpłucoL [ $\left.\mathrm{cm}^{3}\right]$, objętość obu płuc - VPłuca [cm³] (rycina 3).

\begin{tabular}{|c|c|c|c|c|c|}
\hline Structure & Volume $\left[\mathrm{cm}^{3}\right]$ & Dose Cover.[\%] & Min Dose [Gy] & Max Dose [Gy] & Mean Dose [Gy] \\
\hline CTV BOOST & 43.7 & 100.0 & 39.917 & 44.915 & 43.398 \\
\hline Pluco (L) & 1344.7 & 100.0 & 0.678 & 43.276 & 8.620 \\
\hline CTV & 539.9 & 100.0 & 32.908 & 45.320 & 42.959 \\
\hline BODY & 29316.9 & 100.0 & 0.000 & 45.340 & 2.502 \\
\hline Pluca & 2850.1 & 100.0 & 0.000 & 43.236 & 4.307 \\
\hline Cialo & 17371.3 & 100.0 & 0.000 & 45.340 & 4.029 \\
\hline v klatka & 12883.5 & 100.0 & 0.000 & 45.340 & 5.327 \\
\hline Dose 10[\%]s & 59.0 & 100.0 & 4.042 & 43.004 & 21.277 \\
\hline Dose $10[\%] p$ & 430.3 & 100.0 & 4.049 & 43.276 & 22.957 \\
\hline
\end{tabular}

Rycina3. Przykładowe parametry statystyczne z planu leczenia pacjentki z nowotworem piersi z systemu planowania leczenia.

Wybrane narządy krytyczne przeanalizowano zgodnie z wytycznymi raportu QUANTEC [8] oceniano: dawkę zdeponowaną w co najmniej 30\% objętości płuc D(30\%) płuco [Gy], dawkę zdeponowaną w co najmniej 10\% objętości serca - D(10\%) serce [Gy]. Korzystając z narzędzi w SPL wyznaczono obszar objęty 10\% izodozą dawki zadanej w objętości CTV tworząc nową strukturę pomocniczą w SPL. Objętość powyższej struktury odejmowano za pomocą operacji logicznych dostępnych w SPL od konturów serca i płuc. W ten sposób otrzymano dwa kolejne parametry: objętość serca objęta izodozą 10\% dawki zadanej i objętość płuc objęta izodozą 10\% dawki zadanej. Finalnie zdefiniowano dwa parametry: objętość płuc objęta izodozą 10\% dawki zadanej $-\mathbf{V}^{10}{ }_{\mathbf{p}}\left[\mathrm{cm}^{3}\right]$, objętość serca objęta izodozą $10 \%$ dawki zadanej - $\mathbf{V}_{\mathbf{s}}^{\mathbf{1 0}}\left[\mathrm{cm}^{3}\right]$ (rycina 4). Obliczono średnie wartości dawek dla parametrów $\mathbf{V}^{10}{ }_{\mathbf{p}} \mathrm{i} \mathbf{V}^{\mathbf{1 0}}{ }_{\text {s. }}$. Dzięki czemu możliwe było oszacowanie różnicy w dostarczanych dawkach promieniowania jonizującego w zależnie od anatomii analizowanych pacjentek.

Rycina 4. Wizualizacja parametru objętość serca objęta izodozą $10 \%$ dawki zadanej - $\mathrm{V}_{\mathrm{s}}^{10}$ (struktura w kolorze żółtym) dla przykładowej pacjentki w systemie planowania leczenia.




Dodatkowo wprowadzono subiektywny parametr, dzielący badaną grupę pacjentek ze względu na kształt piersi: pierś nieopadająca i pierś opadająca (rycina $5 \mathrm{a}, 5 \mathrm{~b}$ ).

a)

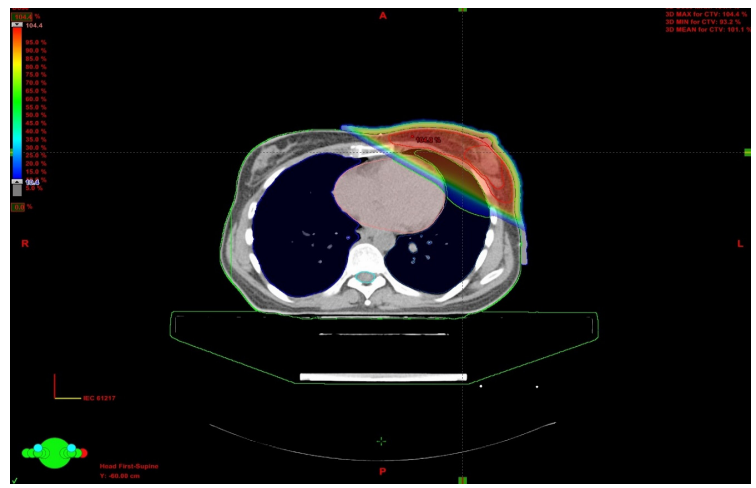

b)

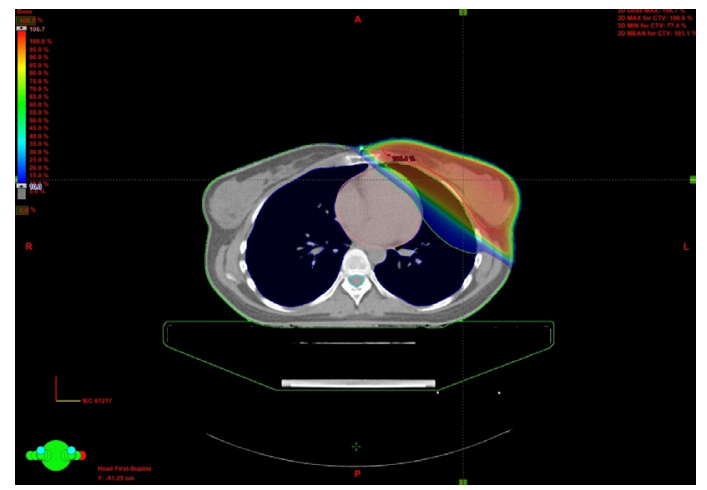

Rycina 5. Wizualizacja subiektywnego podziału pacjentek, ze względu na kształt piersi: a) pierś nieopadająca b) pierś opadająca dla przykładowej pacjentki w systemie planowania leczenia.

W przypadku piersi nieopadających wiązki terapeutyczne swoim wymiarem obejmują mniejszą objętość w głąb klatki piersiowej w porównaniu do piersi opadających. Wśród 50 pacjentek 14 zostało zaklasyfikowanych do grupy posiadających piersi opadające. Wynikało to głównie z wieku analizowanych pacjentek. W grupie pacjentek z piersią nieopadającą najmłodsza chora miała 35 lat, najstarsza 78. Mediana wieku wynosi 6o. Wraz z wiekiem piersi tracą jędrność, opadają w bok w stosunku do klatki piersiowej. Do tej grupy zakwalifikowano 36 pacjentek. Najmłodsza pacjentka w tej grupie miała 37 lat, najstarsza 77 lat. Mediana wynosi 62. Dostarczenie dawki zadanej do całej objętości opadającego gruczołu piersiowego, wymaga ustalenia innej geometrii wiązek tangencjalnych niż w przypadku piersi nieopadającej.

\section{Wyniki}

Otrzymane wyniki dla 50 analizowanych pacjentek pogrupowano według wartości objętości CTV (V CTV) $\left[\mathrm{cm}^{3}\right]$ celem wykazania wpływu objętości CTV na dawki w narządach krytycznych. W całej grupie chorych objętość CTV była konturowana w jednakowy sposób i obejmowała całą lewą pierś, bez dołu pachowego. Przyjęto, że okonturowana objętość CTV odpowiadała wielkości napromienianego gruczołu piersiowego.

Wykazano, że parametr V CTV nie ma bezpośredniego wpływu na dawki w sercu D(10\%) serce (wykres 1) oraz w płucach D(30\%) płuco [Gy] (wykres 2). Dla powyższych parametrów zastosowano korelację Pearsona, wyniki analizy przedstawiono w tabeli 1 za pomocą współczynnika liniowego R i współczynnika korelacji $\mathrm{R}^{2}$ oraz wartości współczynnika p.

Tabela 1. Korelacja Pearsona parametru objętość CTV (V CTV) i dawki w D(10\%) serca oraz D(30\%) płuca, współczynnik liniowy R i współczynnik korelacji $\mathrm{R}^{2}$ oraz wartości współczynnika p.

\begin{tabular}{|c|c|c|c|}
\hline V CTV [cm3] & $\mathbf{R}$ & $\mathbf{R 2}$ & P \\
\hline $\mathrm{D}(10 \%)$ serce [Gy] & 0,310 & 0,096 & 0,028 \\
\hline $\mathrm{D}(30 \%)$ płuca [Gy] & 0,072 & 0,005 & 0,619 \\
\hline
\end{tabular}

Korelując parametry V CTV z parametrem D(10\%) serce, uzyskano współczynnik korelacji R² równy 0,096, a wartość p równą 0,028. Pomimo, że stwierdzono korelację statystyczną, nie ma ona znaczenia klinicznego (wykres 1). 


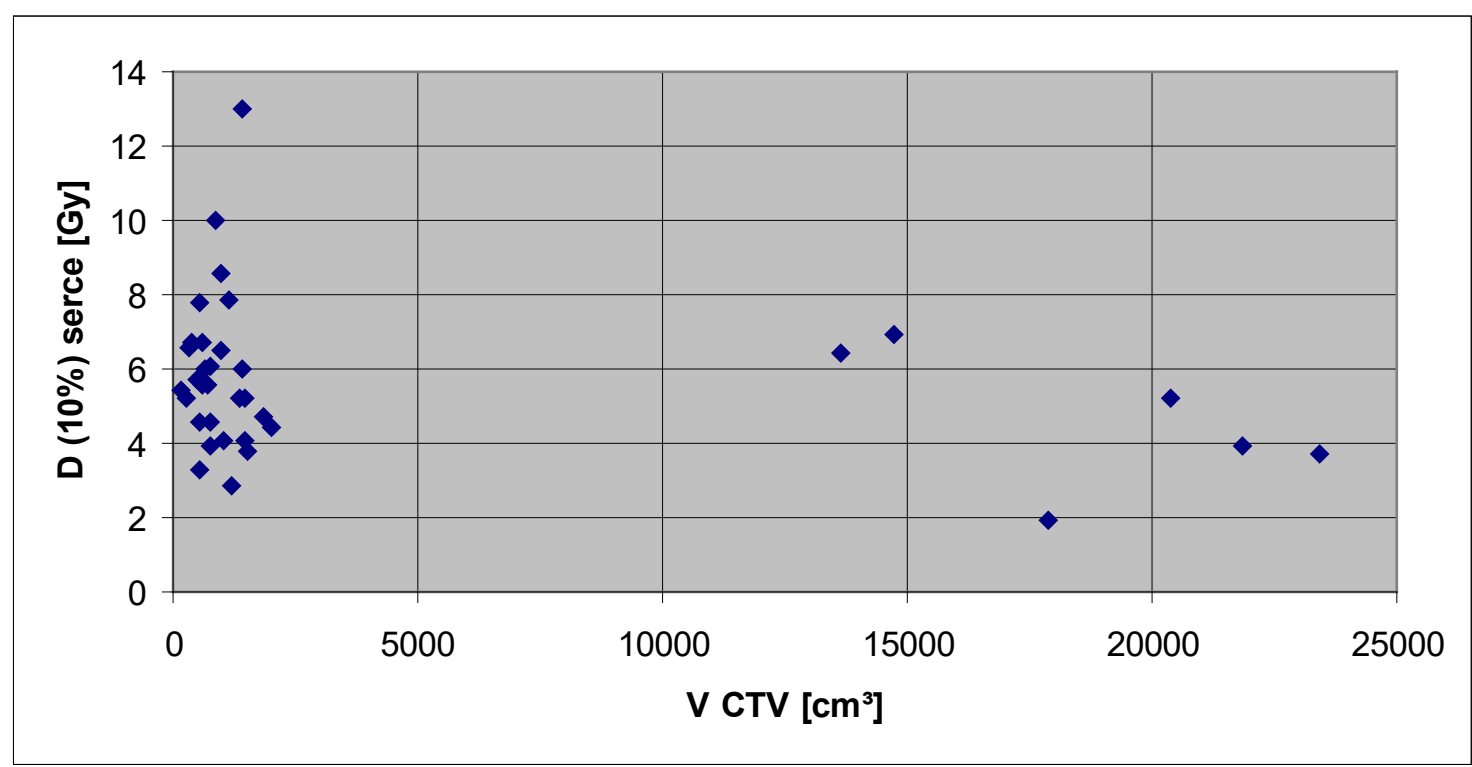

Wykres 1. Zależność pomiędzy objętością gruczołu piersiowego zdefiniowanego jako parametr V CTV [cm³], a wielkością parametru dawka $\mathrm{D}(10 \%)$ serca [Gy].

Parametry V CTV oraz D(30\%) płuco również nie wykazują korelacji p=0,619 (wykres 2).

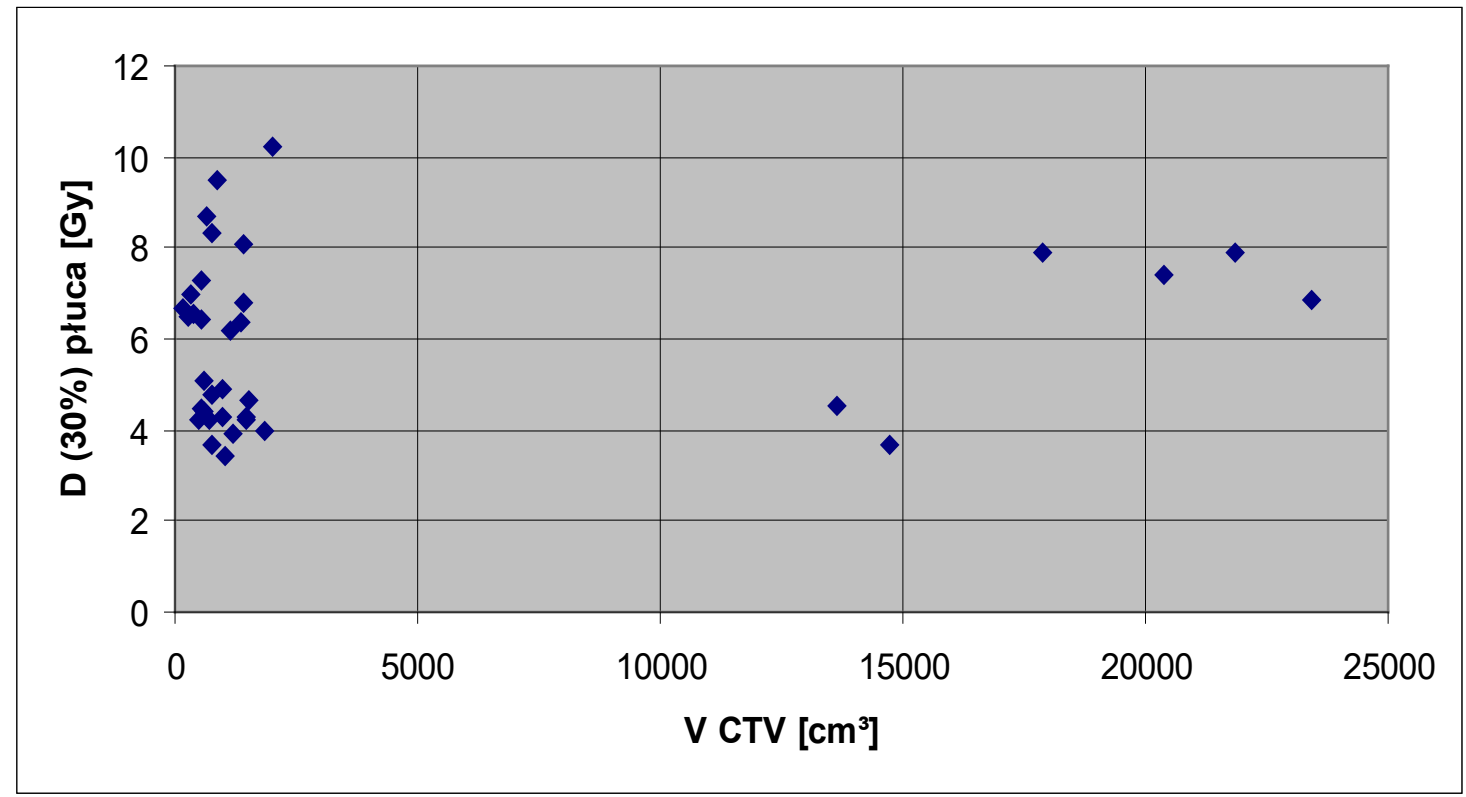

Wykres 2. Zależność pomiędzy objętością gruczołu piersiowego zdefiniowanego jako parametr V CTV [cm³], a wielkością parametru dawki D(30\%) płuca [Gy].

\section{Dawki w narządach zdrowych w zależności od objętości klatki piersiowej}

Kolejnym sposobem wykazania zależności dawek w narządach krytycznych od anatomii była analiza parametru objętość klatki piersiowej - parametr V klatka [Gy]. Nie wykazano jednoznacznej zależności parametru V klatka w stosunku do dawki D(10\%) serce (wykres 3) oraz D(30\%) płuca (wykres 4). Okazało się, iż zwiększająca się objętość klatki piersiowej (V klatka) nie ma bezpośredniego wpływu na geometrię wiązek promieniowania, które determinują wielkość dawki zdeponowanej w narządach krytycznych. Podczas analizy statystycznej nie wykazano korelacji dla parametrów V klatka oraz D(10\%) serca i D(30\%) płuca (tabela 2). 
Tabela 2. Korelacja Pearsona parametru objętość klatki piersiowej (V klatka) i dawki D(10\%) serce i D(30\%) płuca, współczynnik liniowy R i współczynnik korelacji $\mathrm{R}^{2}$ oraz wartości współczynnika p.

\begin{tabular}{|c|c|c|c|}
\hline V klatka & $\mathbf{R}$ & $\mathbf{R}^{2}$ & $\mathbf{p}$ \\
\hline $\mathrm{D}(10 \%)$ serce & $-0,041$ & 0,002 & 0,780 \\
\hline $\mathrm{D}(30 \%)$ płuca & 0,015 & 0,000 & 0,916 \\
\hline
\end{tabular}



Wykres 3. Zależność pomiędzy objętością klatki piersiowej zdefiniowanej jako parametr V klatka [cm³], a wielkością parametru dawka $\mathrm{D}(10 \%)$ serca [Gy].

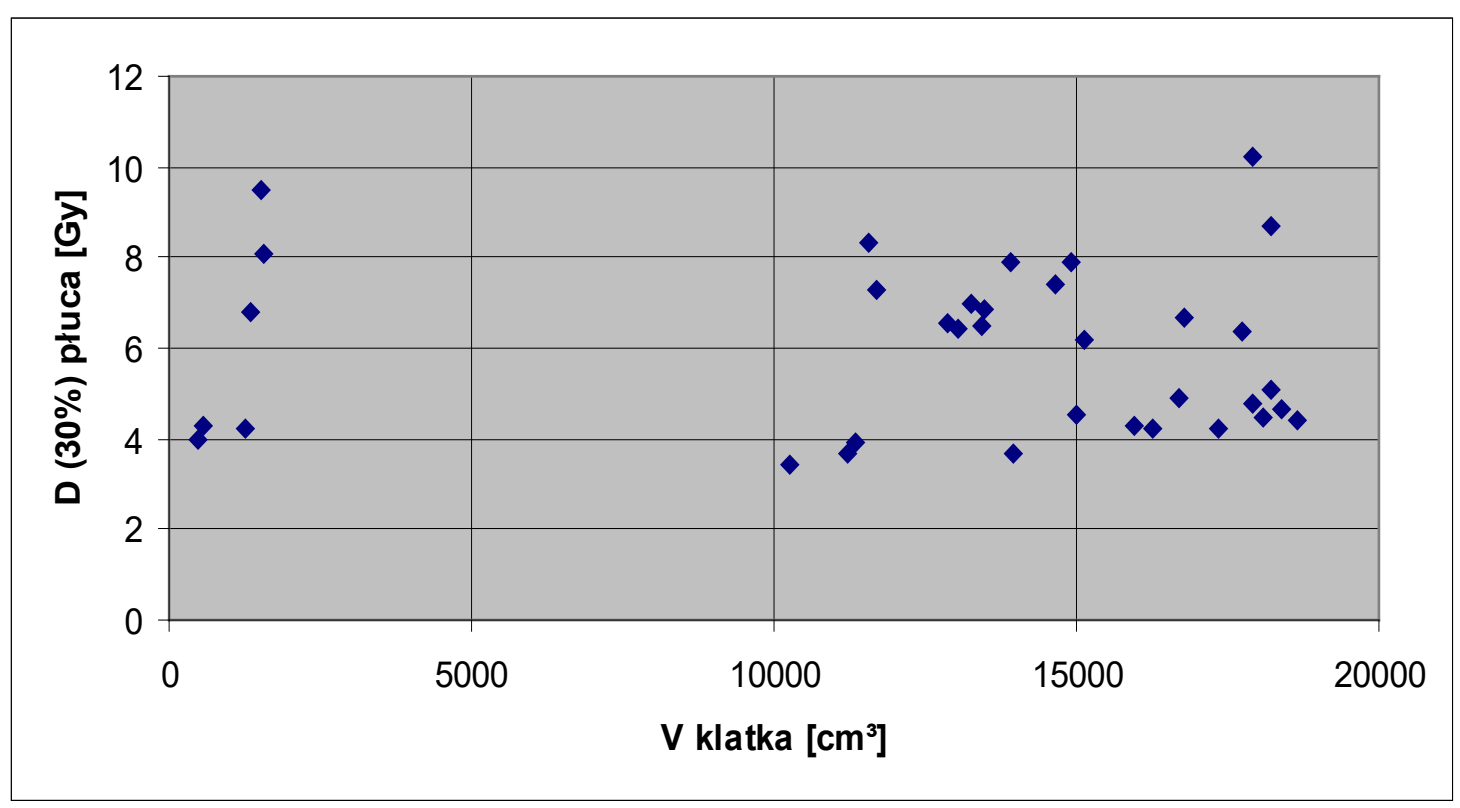

Wykres 4. Zależność pomiędzy objętością klatki piersiowej zdefiniowanej jako parametr V klatka [cm3], a wielkością parametru dawka $\mathrm{D}(30 \%)$ płuca [Gy]. 


\section{Dawki w narządach zdrowych w zależności od ułożenia piersi}

Kolejnym parametrem, według którego pogrupowano otrzymane dawki w narządach krytycznych był podział uwzględniający objętość narządów krytycznych: serca i płuc objętych izodozą 10\% dawki $\mathbf{V}^{10}$ i $\mathbf{V}^{10}$ $\left[\mathrm{cm}^{3}\right]$. Okazało się, iż ten sposób klasyfikacji najlepiej ukazuje wpływ anatomii na dawki w narządach, co ilustruje wykres 5 i 6 . Wyraźnie widać zależność pomiędzy wyżej wymienionymi parametrami $\mathbf{V}^{10}$ i $\mathbf{V}^{10}$, a dawką w narządach krytycznych mierzoną w 10\% objętości serca i 30 \% objętości płuc (odpowiednio w: $\mathrm{D}(10 \%)$ serce i $\mathrm{D}(30 \%)$ płuco). Widoczny jest następujący trend, im większa jest wartość parametru $\mathbf{V}^{\mathbf{1 0}}$ s (wykres 5) i $\mathbf{V}^{10}$ (wykres 6), z uwzględnieniem podziału na pierś nieopadającą i opadającą, tym większa dawka pochłaniana jest w badanych objętościach serca i płuc D(10\%) serce i D(30\%) płuco. Parametry $\mathbf{V}^{\mathbf{1 0}}$ i $\mathbf{V}^{10}$ są zależne od jędrności piersi poddawanych radioterapii (parametr subiektywny - wprowadzony przez autora).

Tabela 3. Korelacja Pearsona parametru parametrów $\mathbf{V}^{\mathbf{1 0}}$ i $\mathrm{D}(10 \%)$ serce oraz $\mathrm{z}_{\mathbf{s}} \mathbf{V}_{\mathbf{p}}^{\mathbf{1 0}}$ i $\mathrm{D}(30 \%)$ płuco, współczynnik liniowy R i współczynnik korelacji R2 oraz wartości współczynnika p.

\begin{tabular}{|c|c|c|c|}
\hline Zależność & $\mathbf{R}$ & $\mathbf{R}^{2}$ & $\mathbf{p}$ \\
\hline $\mathbf{V}_{\mathbf{s}}^{\mathbf{1 0}} / \mathrm{D}(10 \%)$ serce & 0,871 & 0,758 & $<0,0001$ \\
\hline $\mathbf{V}_{\mathbf{p}}^{10} / \mathrm{D}(30 \%)$ płuco & 0,769 & 0,592 & $<0,0001$ \\
\hline
\end{tabular}



Wykres 5.Zależność pomiędzy parametrem $\mathrm{V}^{10}{ }_{s}$, opisującego objętość serca, objętą izodozą 10\% dawki zadanej [cm³] a wielkością parametru D (10\%) serce [Gy] z podziałem na pacjentki posiadające pierś nieopadającą (kolor zielony) oraz pierś opadającą (kolor czerwony). 


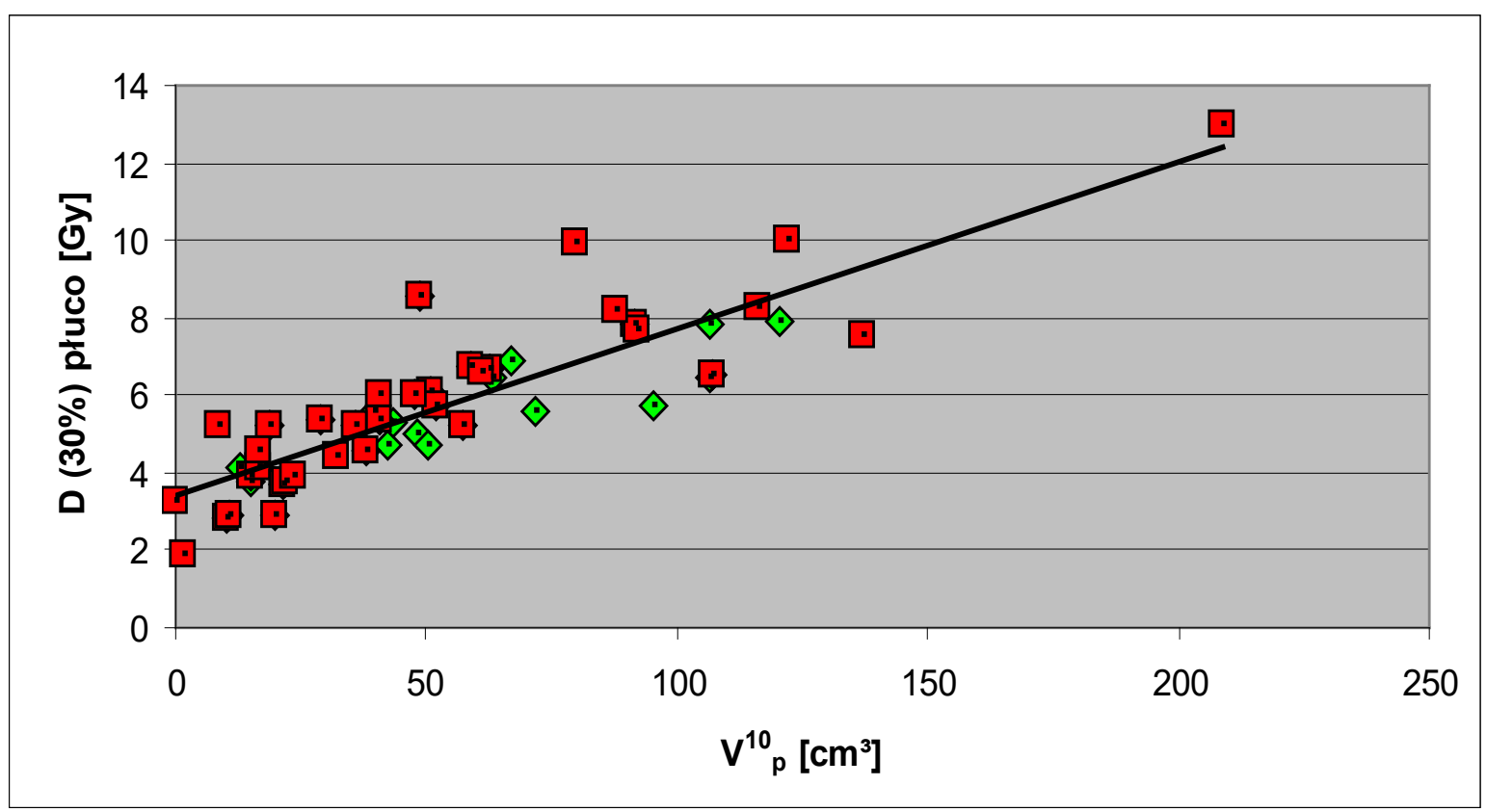

Wykres 6. Zależność pomiędzy parametrem $\mathrm{V}^{10}$ p opisującego objętość płuc objętą izodozą 10\% dawki zadanej [cm3], a wielkością parametru D (30\%) płuca [Gy] z podziałem na pacjentki posiadające pierś nieopadającą (kolor zielony) oraz pierś opadającą (kolor czerwony).

Przeprowadzono test nieparametryczny Mann’a - Whitney’a zestawiając ze sobą kolejno parametry $\mathrm{D}(10 \%)$ serce, $\mathbf{V}^{\mathbf{1 0}}$ s oraz $\mathrm{D}(30 \%)$ płuco i $\mathbf{V}^{10}$ w dwóch podgrupach pacjentek, pacjentek z piersią nieopadającą i opadającą. Wyniki przedstawiono w tabeli 4.

Tabela 4. Test nieparametryczny Mann’a - Whitney’a przedstawiający wartość p parametru D(10\%) serce, $\mathrm{V}^{10}, \mathrm{D}(30 \%)$ płuco i $\mathrm{V}_{\mathrm{p}}^{10} \mathrm{w}$ dwóch grupach - pacjentek z piersią nieopadającą i opadającą.

\begin{tabular}{|c|c|c|c|c|}
\hline $\mathbf{P}$ & $\mathbf{D ( 1 0 \% )}$ serce & $\mathbf{V}^{\mathbf{1 0}}{ }_{\mathbf{s}}$ & $\mathbf{D ( 3 0 \% )} \mathbf{p ł u c o}$ & $\mathbf{V}_{\mathbf{p}}^{\mathbf{1 0}}$ \\
\hline nieopadająca / opadająca & 0,854 & 0,184 & $<0,0001$ & $<0,0001$ \\
\hline
\end{tabular}

Otrzymane wyniki wskazują, że istnieje wyraźna zależność pomiędzy porównywanymi parametrami $\mathrm{D}(30 \%)$ płuco i $\mathbf{V}^{10}{ }_{\mathbf{p}}$.

\section{Dyskusja}

Otrzymane wyniki wskazują, że dawka jaką otrzymują narządy krytyczne (wytyczne z raportu QUANTEC: 30\% objętości płuc nie może otrzymać dawki większej niż $20 \mathrm{~Gy}$, 10\% serca nie może otrzymać dawki większej niż 25 Gy) [8]. Powyższe dawki deponowane w procesie radioterapii gruczołu piersiowego, nie zależą bezpośrednio od wielkości piersi (objętość CTV), ani od objętości klatki piersiowej zdefiniowanej jako parametr V klatka. Parametr opisujący objętość CTV, w tym przypadku uwzględnia tylko rozmiar piersi napromienianej, nie uwzględnia ani kształtu, ani położenia CTV względem klatki piersiowej. Istotnym jest podkreślenie, że rozmiar piersi prowadzi do zwiększenia dawki w sercu i maksymalnej dawki na skórze, przy czym dawki w sercu nadal pozostają w granicach dawek tolerancji $[12,13]$. Należy pokreślić, że obszar płuc i serca objęty dawką terapeutyczną zależy od geometrii wiązek tangencjalnych, a ta z kolei jest zależna od ułożenia piersi w pozycji terapeutycznej pacjentki [12]. Położenie napromienianego gruczołu ma największy wpływ na dawki otrzymywane przez serce i płuca w procesie radioterapii. Autorzy w swojej pracy również podnieśli kwestie wpływu anatomii pacjentek z nowotworem piersi na dawki w narządach krytycznych, idąc jeszcze krok dalej szacując spersonalizowane ryzyko [13]. W przypadku piersi nieopadającej możliwe jest takie 
ustawienie wiązek, które pozwoli dostarczyć dawkę terapeutyczną do całego gruczołu piersiowego, obejmując mniejszy obszar klatki piersiowej. Mniejsza objętość serca i płuc otrzymuje wysoką dawkę promieniowania jonizującego. W pracy wprowadzono parametry $\mathrm{V}^{10}{ }_{\mathrm{s}}$ oraz $\mathrm{V}^{10}$ przedstawiające objętość serca i płuc objęta izodozą 10\% dawki zadanej. Na podstawie tych parametrów możliwe było stwierdzenie, że w przypadku pacjentek z piersią nieopadającą, mniejsza objętość płuc otrzymuje wyższą dawkę promieniowania jonizującego, ze względu na geometrię wiązek tangencjalnych, które muszą być zorientowane w taki sposób, aby objąć całą pierś. Dawki w sercu nie różnią się znacząco w obu przeanalizowanych podgrupach: pacjentek posiadających pierś nieopadającą i opadającą.

Wysokie dawki w narządach krytycznych wynikające z anatomii pacjentek można dodatkowo ograniczyć stosując techniki napromieniania na głębokim wstrzymanym wdechu. Podczas wdechu tkanka płuca rozpręża się i odsuwa serce od ściany klatki piersiowej, tym samym przesuwa się poza obszar wysokiej dawki promieniowania $[18,19]$. Technika ta pozwala na wykorzystanie fizjologii procesu oddychania, przy czym wymaga zainstalowania odpowiedniej technologii na akceleratorze liniowym i tomografie komputerowym umożliwiającą kontrolę oddechu oraz dedykowanego modułu w systemie planowania leczenia. Dane pracy Hannan i wsp. sugerują, że hipofrakcjonowana radioterapia z użyciem technik dynamicznych jest odpowiednią metodą terapeutyczną u pacjentów z dużymi piersiami [13]. Metody te należy stosować zawsze, kiedy jest to możliwe. Niestety nie wszystkie ośrodki radioterapii posiadają tak zaawansowane techniki leczenia. W szczególnie niekorzystnej sytuacji są także pacjentki, u których występują dodatkowo choroby ograniczające objętość płuc (np. astma, obturacyjna choroba płuc). Poza tym nie wszystkie chore w podeszłym wieku są w stanie współpracować podczas procedury DIBH. W tych wyjątkowych przypadkach zdarza się, że po przygotowaniu planu leczenia bez zastosowania napromieniania na wstrzymanych wdechu, dawki w narządach krytycznych są nieakceptowalne i rezygnuje się z leczenia radykalnego. Aby tego uniknąć przeanalizowano teoretycznie inne możliwe unieruchomienia pacjentek z nowotworem piersi. Jednym z nich jest zastosowanie specjalnych staników do pozycjonowania piersi. Pierś zmienioną nowotworowo umieszcza się $\mathrm{w}$ miseczce $\mathrm{z}$ transparentnego dla promieniowania jonizującego materiału. Dzięki czemu gruczoł piersiowy jest uniesiony i nie opada. Finalnie wiązki tangencjalne obejmują mniejszą objętość płuc i serca. Możliwe jest również zastosowanie termoplastycznych unieruchomień na obszar klatki piersiowej. Powodują one uniesienie piersi ze zmianą nowotworową, jednocześnie redukując dawkę w sercu i płucach.

Inną metodą jest ułożenie pacjentki w pozycji na brzuchu z zastosowaniem dedykowanej podstawki, gdzie napromieniana pierś umieszczona jest w specjalnym otworze [15]. Wymusza to zastosowanie zupełnie innej geometrii wiązek tangencjalnych, niż w przypadku klasycznej pozycji pacjentek podczas radioterapii piersi $[16,17]$. Pierś nie opada na klatkę piersiową, dzięki czemu możliwe jest znaczne oszczędzenie płuc i serca. Taka pozycja ułożenia pacjentki sprawia, że pierś swobodnie zwisa w dół, cała objętość CTV zmienia swoje położenie. Możliwe jest objęcie całego gruczołu dawką terapeutyczną, jednocześnie omijając płuca. Niestety, w praktyce pozycja na brzuchu podczas terapii jest trudniejsza do pozycjonowania podczas codziennych frakcji radioterapii, powodując większe komplikacje w prawidłowym ułożeniu pacjentek [19].

\section{Wnioski}

W przypadku pacjentek poddanych radioterapii gruczołu piersiowego, jego wielkość nie wpływa bezpośrednio na objętość serca i płuc objętych dawką terapeutyczną. Determinująca nie jest również objętość klatki piersiowej. Objętość narządów krytycznych objętych dawką terapeutyczną przy zastosowaniu standardowych unieruchomień zależy od jędrności gruczołu - jego ułożenia względem ściany klatki piersiowej. Im większa pierś opadająca tym większy musi być wymiar wiązki terapeutycznej. Oznacza to, iż większa dawka promieniowania jest dostarczana do narządów zdrowych. Jeżeli jest taka możliwość, należy zastosować inne, bardziej konformalne techniki wraz ztechniką DIBH. W szczególnych przypadkach pacjentek posiadających duże piersi opadające, u których choroby układu oddechowego wykluczają zastosowanie wyżej wymienionej metody, korzystne stosowanie innych niż standardowe unieruchomienia. 


\section{Konflikt interesu/Conflict of interest}

Nie występuje. / None.

\section{Etyka/Ethics}

Treści przedstawione $\mathrm{w}$ artykule są zgodne $\mathrm{z}$ zasadami Deklaracji Helsińskiej, dyrektywami EU oraz ujednoliconymi wymaganiami dla czasopism biomedycznych. / The contentpresented in the articleisconsistent with the principles of the Helsinki Declaration, EU directives and unifiedrequirements for biomedicalmagazines.

\section{Piśmiennictwo/References}

[1] http://onkologia.org.pl/

[2] Bray F, Ferlay J, Soerjomataram I, et al. Global cancer statistics 2018: GLOBOCAN estimates of incidence and mortality worldwide for 36 cancers in 185 countries. CA Cancer J Clin. 2018;68:394-424.

[3] Moran MS, Schnitt SJ, Giuliano AE, et al. Society of Surgical Oncology-American Society for Radiation Oncology consensus guideline on margins for breast-conserving surgery with whole-breast irradiation in stages I and II invasive breast cancer. Ann Surg Oncol. 2014; 21:704-16.

[4] Darby S, McGale P, Correa C, et al. Review Effect of radiotherapy after breast-conserving surgery on 10-year recurrence and 15-year breast cancer death: meta-analysis of individual patient data for 10,801 women in 17 randomised trials. Early Breast Cancer Trialists' Collaborative Group (EBCTCG)., Lancet. 2011; 378:1707-16.

[5] Chen S.N, Ramachandran P, Deb P. Dosimetric comparative study of 3DCRT, IMRT, VMAT, Ecomp, and Hybrid techniques for breast radiation therapy Radiat Oncol J. 2020;38: 270-81.

[6] . Zhang Q, Yu XL, Hu WG, et al. Dosimetric comparison for volumetric modulated arc therapy and intensity-modulated radiotherapy on the left-sided chest wall and internal mammary nodes irradiation in treating post-mastectomy breast cancer. Radiol Oncol. 2015; 49:91-8.

[7] Nantavithya C, Saksornchai K, Oonsiri P et al. Dosimetric study of three-dimensional conformal radiotherapy, electronic compensator technique, intensity-modulated radiation therapy and volumetricmodulated arc therapy in whole breast irradiation. RadiotherPract. 2017;16:431-43.

[8] Bentzen S.M, Constine L.S, Deasy J.O, et al. Quantitative Analyses of Normal Tissue Effects in the Clinic (QUANTEC): An Introduction to the Scientific Issues. Int J Radiat Oncol Biol Phys. 2010;76:3-9.

[9] ICRU Report 50. Prescribing, Recording and Reporting Photon Beam Therapy. International Commission on Radiation Units and Measurements 1993,

[10] ICRU Report 62. Prescribing, Recording and Reporting Photon Beam Therapy (Supplement to ICRU Report 50). International Commission on Radiation Units and Measurements 1999,

[11] Gagliardi G, Constine L. S, Moiseenko V, et al. Radiation dose - volume effects in the heart, Int J Radiat Oncol Biol Phys. 2010;76:77-85.

[12] Drost L, Yee C, Lam H, et al. A Systematic Review of Heart Dose in Breast Radiotherapy, Clin Breast Cancer, 2018 Clin Breast Cancer 2018;18:819-24.

[13] Hannan R, Thompson R.F, Chen Y, et al. Hypofractionated Whole-Breast Radiation Therapy: Does Breast Size Matter? Int J Radiat Oncol Biol Phys. 2012;84:894-901.

[14] Kundrát P, Simonetto C, Eidemüller M, et al. What anatomic features govern personal long-term health risks? RadiatProt Dosimetry 2019;186:381-5.

[15] Stewart D, Ambat J, Wallis S, et al. Breast radiotherapy using a breast cup: moving the target, not the patient. PractRadiat Oncol. 2020;10:238-43.

[16] Takahashi K, Morota M, Kagami Y, et al. Prospective study of postoperative whole breast radiotherapy for Japanese large-breasted women: a clinical and dosimetric comparisons between supine and prone positions and a dose measurement using a breast phantom, BMC Cancer. 2016;16:757

[17] Yao S, Zhang Y, Nie K, Setup uncertainties and the optimal imaging schedule in the prone position whole breast radiotherapy Radiat Oncol. 2019;14:76. 
[18] Shah C, Badiyan S, Berry S, et al. Cardiac dose sparing and avoidance techniques in breast cancer radiotherapy, Radiother Oncol. 2014;112:9-16.

[19] Lai J, Hu S, Luo Y, et al. Meta-analysis of deep inspiration breath hold (DIBH) versus free breathing (FB) in postoperative radiotherapy for left-side breast cancer, Breast Cancer. 2020;27:299-307. 